廢스마트 琉璃製品 再活用 現況과 技術 展望

中洪鉉善・曹奉圭*

高等技術研究院 新素材工程센터

*韓國地質資源研究院 廢金屬有用資源再活用事業團

\title{
Overview and Future Concerns for Recycling Glass Wastes
}

\author{
*Hyun Seon Hong and Bong-Gyoo Cho* \\ Institute for Advanced Engineering (IAE), Yongin, Korea \\ *R\&D Center for Valuable Recycling (KIGAM), Daejeon, Korea
}

\section{요 약}

유리소재는 금속과는 다른 세라믹의 특성 때문에 오랜 기간 인류가 지속적으로 사용한 소재로서, 현대에 산업이 고도화되면서 유 리소재도 고도화되어 스마트 유리가 개발되어 사용되고 있다. 스마트 유리는 주로 디스플레이, 반도체 등에서 사용되고 있는 고기 능성 첨단유리 제품으로, 사용 후 유리 발생량이 계속 증가하고 있는 추세이며 2012년의 경우 적어도 60,000 톤 이상의 폐기물이 발 생한 것으로 추정된다. 본 고에서는 국내 스마트 유리산업 및 재활용 현황을 살펴보고, 국내의 재활용기술과 향후 전망에 대해 요 약 소개하고자 한다.

주제어 : 스마트 유리, 국내 산업현황, 재활용 현황, 재활용 기술

\begin{abstract}
Glass materials possess unique functional characteristics of ceramics different from those of metals, which has marked glass as one of the mainstay materials in the history of mankind. Nowadays, industrial sophistication necessitates comparable "smart" attributes of glass materials as a significantly advanced form of sophistication. Smart glasses are increasingly applied in many state-of-the-art digital appliances such as displays and semiconductors and waste is also expected to accumulate therefrom in the near future: More than 60,000 tons of smart glass wastes were reported as of 2012, for example. In the present paper, current status of domestic Korean smart glass industry and related recycling enterprise have been comprehensively investigated. Finally, Korean domestic smart glass recycling technology and its future prospect are also briefly presented.
\end{abstract}

Key words : smart glass material, korean smart glass industry, recycling status, recycling technology

\section{1. 서 \\ 론}

유리는 높은 광 투과성, 내열성, 화학적 안정성, 경제
성, 심미성 등의 특성으로 인해 고대시대부터 현재에 이 르기까지 지속적으로 사용되고 있으며, 일상용품에서부 터 산업용까지 폭 넓은 범위에서 꾸준하게 활용되고 있

\footnotetext{
* Received : March 8, 2013 - Revised : April 29, $2013 \cdot$ Accepted : May 20, 2013

₹Corresponding Author : Hyun Seon Hong (E-mail : hshong@iae.re.kr)

Advanced Materials \& Processing Center, Institute for Advanced Engineering, Goan-ro 51 road, Baegam-myeon, Cheoin-gu, Yongin-si, Gyeonggi-do, 449-863, Korea

Tel : +82-31-330-7481 / Fax : +82-31-330-7113

(c) The Korean Institute of Resources Recycling. All rights reserved. This is an open-access article distributed under the terms of the Creative Commons Attribution Non-Commercial License (http://creativecommons.org/licenses/by-nc/3.0/), which permits unrestricted non-commercial use, distribution and reproduction in any medium, provided the original work is properly cited.
} 
다. 특히 현재 IT, 전기전자기술 등이 발달함에 따라 유리 소재의 기술개발도 함께 진행되어 스마트유리(smart glass) 산업이 성장하고 있는 실정이다. 스마트유리란 기존의 병 유리, 창문 유리와 같은 전통 유리와 차별화하여 조명/디 스플레이, 반도체, 태양전지 분야 등에서 다양한 용도로 사용되고 있는 고기능성 첨단유리 제품을 일컫는다.

스마트유리 국내시장규모를 품목별로 보면, 2010년 기준으로 디스플레이유리가 약 7.5 조 원으로 전체의 $86 \%$ 를 차지하고 있고, 석영유리가 0.8 조 원(약 $10 \%$ ), 광학유리가 0.2 조 원(약 $2 \%$ )를 나타내고 있다. ${ }^{1)}$ 스마트 유리 품목 전체에 대한 향후 국내시장전망을 보면, 2015년까지 연간 5 10\%의 성장률을 나타낼 것으로 예측되고 있어서 2013년에는 약 11조 원, 2015년에는 현재보다 1.5 배 수준인 약 13 조 원에 도달할 것으로 분석되고 있다.

재활용 측면에서 전통유리인 병유리의 경우 음식료품 류, 세제류, 주류, 의약품류 등에 사용된 유리병이 EPR (Extended Product Responsibility) 대상이다. 2007년 기준 $\mathrm{EPR}$ 대상 유리병 출고량은 458,000 여 톤이고, 재 활용된 량은 360,000 여 톤으로 $80 \%$ 정도의 재활용율을 보이고 있다. 반면 스마트유리 품목의 경우, 폐유리 발 생량 통계가 체계적으로 파악되지 않고 있는 실정이나, 추정치 등을 포함할 경우 전체 발생량은 Fig. 1에서 보듯

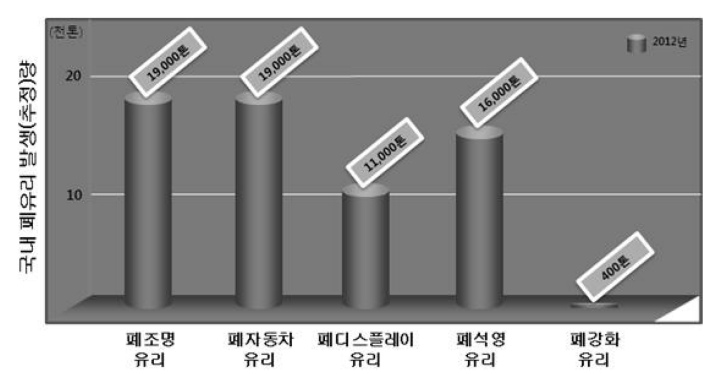

Fig. 1. Production rate of waste glass in Korea. ${ }^{3)}$
이 연간 6 만여 톤 정도일 것으로 판단할 수 있다. ${ }^{2)}$ 본 고에서는 국내 유리 산업현황 및 재활용 시장을 살펴보 고, 국내의 재활용기술과 재활용 현황, 향후 전망에 대 해 요약 소개하고자 한다.

\section{2. 유리산업 및 재활용 기술 현황}

\section{1. 조명유리}

2.1.1. 제조 및 생산현황

조명기기의 분류는 광원에 의한 분류로 방사램프, 방 전램프, 차세대 램프 3 가지로 분류하면 현재까지 사용 되는 모든 조명은 Table 1과 같은 범주에 속한다. 통계 청 2011년 자료에 의하면 조명 산업과 관련한 국내 연 도별 생산 현황은 2009년도에 4조 1,203억원으로 연평 균 전체 성장률은 $5.8 \%$ 를 나타내었고, 2011년 한국무 역협회 자료에 의하면 조명산업 수출 현황은 2010년 기준 7억 93,591 US천 달러로 연평균 증가율은 $9 \%$ 로 보고되었다.

\subsection{2. 폐유리 발생현황}

국내 폐형광등은 한국조명재활용공사(주)에서 재처리 되며, 전국적으로 3 개소가 운영되고 있고, 사업장은 경 기 화성, 경북 칠곡, 전남 장성에 위치하고 있다. 현재 설치되어 있는 폐형광등 처리시설을 이용하여 폐형광등 무해화 처리가 이루어지고 있으며 국내에서 폐형광등 수 거 절차는 Fig. 2와 같다. ${ }^{4)}$ 현재 한국조명재활용공사(주) 에서 수집하여 재활용 처리가 되는 폐조명은 전체의 $25 \sim 30 \%$ 로 상당히 낮은 수준이다(Table 2 참조). 이렇 게 낮은 이유는 1 차 발생원 및 수집과정에서 파손되어 분리수거를 하지 않고 단순히 배출하거나 이를 일반 유 리로 분류하여 배출하기 때문인 것으로 판단된다.

한편, 폐형광등을 제외한 가로등, 자동차 램프, 디스 플레이에서 발생되는 유리(냉음극관 등)는 수거 자체가

Table 1. Classification of light devices by source and lamp usages

\begin{tabular}{|c|c|c|c|}
\hline 대분류 & \multicolumn{3}{|c|}{ 광원 } \\
\hline 중분류 & 방사램프 & 방전램프 & 차세대 광원 \\
\hline \multirow{2}{*}{ 소분류 } & $\begin{array}{c}\text { 백열전구 } \\
\text { 할로겐램프 }\end{array}$ & $\begin{array}{c}\text { 형광램프(냉/음극) } \\
\text { 나트륨램프, 고압수은램프 } \\
\text { 메탈할라이드, 제논램프 }\end{array}$ & $\begin{array}{c}\text { LED램프, OLED램프 } \\
\text { 화학발광램프 } \\
\text { CNT 기반 램프 }\end{array}$ \\
\hline \multirow{2}{*}{ 사용처 } & 실내조명, 가로등 조명 등 & $\begin{array}{c}\text { 차량조명, 터널조명, 무대조명, 가로등, } \\
\text { 인테리어 조명 등 }\end{array}$ & $\begin{array}{c}\text { 반도체 조명, 디스플레이 조명, } \\
\text { 가로등 조명 등 }\end{array}$ \\
\hline
\end{tabular}




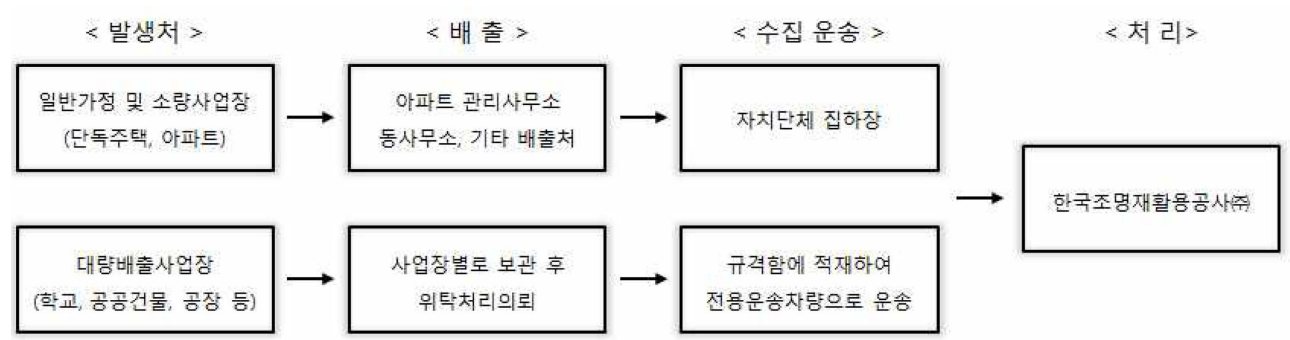

Fig. 2. Schematics of the collection steps for the domestic waste fluorescent lamp. ${ }^{4)}$

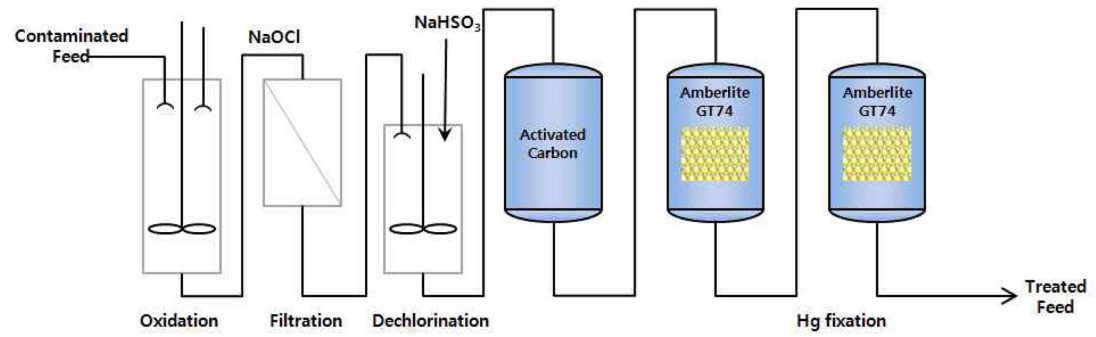

Fig. 3. Scheme of mercury $(\mathrm{Hg})$ removal process by chlorine cementation methods.

법적으로 의무규정이 없고 수거를 전문적으로 처리하는 업체가 없는 실정이다. 이러한 이유는 형광등과 달리 규 격 자체가 표준화되어 있지 않기 때문에 수거를 해도 이를 처리하는 기술이 없기 때문이다. 또한, 기술이 있 다 하더라도 경제성을 고려하여 사업성이 있어야 전문 적으로 처리하는 업체가 생겨날 것으로 기대된다.

\subsection{3. 재활용 기술 및 산업 현황}

폐형광등 재활용기술에 있어서 가장 중요한 부분은 수은의 안정적 처리에 있는데 이에 대한 기술은 크게 건식방법과 습식방법으로 분류할 수 있다. 건식방법은 수은증기를 냉각 응축하여 포집하여 제거하는 방법이다. 습식방법은 금속산화제를 사용하여 침전법으로 수은을 제거하는데 공정도를 Fig. 3에 나타내었다.5)

국내에서 폐형광등 재활용 기술 연구가 진행되었으나 국내 기술을 적용한 사례는 현재까지 없는 실정이고 기 술 개발의 성과는 특허부분에 있어서 산학연 중심으로
많이 출원되고 있다. 특히 폐유리를 이용한 발포체, 보 도블럭, 보온재 등 그 활용 범위가 넓어진 것을 알 수 있다. 국내기술을 이용한 폐형광등 실용화 기술은 현재 까지 전무한 실정이나 최근에는 산연 중심으로 외국 기 술이 아닌 국내 원천기술개발에 박차를 가하고 있으며 이와 관련하여 경기대에서는 건식방법에 의한 폐형광등 절단 및 무해화처리 공정기술, 고등기술연구원에서는 폐 디스플레이 조명에 사용되는 $\mathrm{CCFL}$ 의 재활용 기술개발 등 추진하고 있다. 선진국의 폐형광등 재활용 현황을 보 면 가장 앞선 나라가 독일로 평가되며 폐형광등 처리 후의 수은의 회수율은 물론이고 순도까지 세계 최고 수 준이라 평가된다. ${ }^{6)}$

\section{2. 자동차유리}

2.2.1. 제조 및 생산현황

자동차용 유리는 접합유리(laminated glass)와 강화유 리(tempered glass)로 구분할 수 있으며, 각 부위별로

Table 2. Production rates of waste light glass at 20114)

\begin{tabular}{|c|c|c|}
\hline 구분 & 국내 전체 & $\begin{array}{c}\text { 재활용 처리 } \\
\text { (한국조명재활용공사(주)) }\end{array}$ \\
\hline 폐조명기구 발생량(만개/년) & 15,500 & 3,800 \\
\hline 폐조명용 유리 발생량(톤/년) & 19,000 & 4,500 \\
\hline
\end{tabular}

J. of Korean Inst. Resources Recycling Vol. 22, No. 4, 2013 
Table 3. Production and shipment status of the automotive glass ${ }^{7)}$

\begin{tabular}{|c|c|c|c|c|c|c|c|c|c|}
\hline \multicolumn{3}{|c|}{ 구분 (연도) } & 2005 & 2006 & 2007 & 2008 & 2009 & 2010 & 2011 \\
\hline \multirow{4}{*}{$\begin{array}{l}\text { 자동차용 } \\
\text { 유리 }\left(\mathrm{m}^{2}\right)\end{array}$} & \multicolumn{2}{|c|}{ 생산량 } & $33,533,141$ & $29,928,205$ & $30,180,151$ & $27,417,116$ & $23,841,478$ & $31,665,462$ & $35,436,807$ \\
\hline & \multirow{2}{*}{ 출하량 } & 내수량 & $32,901,614$ & $29,728,133$ & $30,378,737$ & $28,158,927$ & $23,489,052$ & $30,705,627$ & $35,207,580$ \\
\hline & & 수출량 & 62,575 & 63,671 & 75,298 & 54,544 & 35,357 & 40,819 & 78,409 \\
\hline & \multicolumn{2}{|c|}{ 증감율 (\%) } & & -10.8 & 0.8 & -9.2 & -13.0 & 32.8 & 11.9 \\
\hline
\end{tabular}
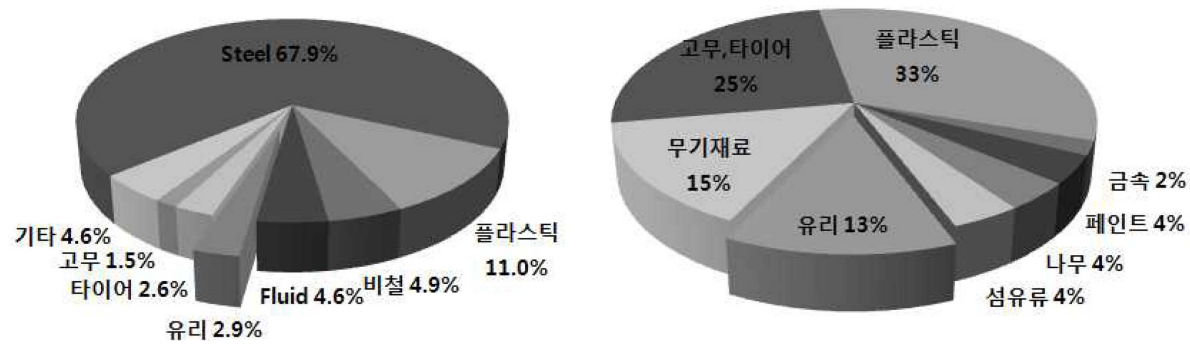

Fig. 4. (a) components of wasted car and (b) ASR component ratio."

앞 유리는 접합유리, 옆 유리 및 뒤 유리는 강화유리로 구성되어있다. 접합유리는 일반판유리 사이에 고충격 저 항을 갖는 합성수지 필름을 삽입하여 일반유리의 취약 점을 역학적인 측면에서 보완하였다. 접합유리는 충격 흡수성이 있어 자동차가 충돌할 때 탑승자의 안전을 지 켜주며 유리가 파손될 때에는 유리 파편이 비산되지 않 아 탑승자의 피해를 극소화시켜준다. 강화유리는 $3 \sim 5 \mathrm{~mm}$ 의 일반유리를 열처리, 성형 가공한 제품으로 일반판유리보다 $3 \sim 5$ 배의 강도를 가지고 있다.

자동차용 유리의 생산 및 출하현황을 살펴보면, 2006 년부터 2009년까지는 글로벌 경기침체의 여파로 생산 량이 전년도에 비해서 동일하거나 감소하는 경향이 나 타났지만 2010년에는 전년도 대비 약 $33 \%$ 의 높은 증 가율을 나타내며 생산량이 급증하였다(Table 3). 2011년 에는 약 3 천 5 백만 평방미터의 자동차용 유리가 생산되 고 있으며 최근 국내자동차업체의 세계판매량이 증가하 는 상황을 감안한다면 앞으로 자동차용 유리의 생산량 은 더욱 증가할 것으로 예상된다.

\subsection{2. 폐유리 발생현황}

Fig. 4와 같이, 자동차에 사용되는 소재 구성은 주로 철(68\%)과 플라스틱(11\%)으로 되어있으며, 유리의 경 우 전체 소재의 $2.9 \%$ 를 차지하고 있다. ${ }^{8)}$ 일반적으로 소형차에는 $30 \mathrm{~kg}$ 의 유리가 포함되어 있으므로, 2011년 승용 폐차대수(약 65 만대, 한국자동차해체재활용업협회 통계자료)를 감안하면 폐유리는 연간 19,000 톤이 발생
할 것으로 추산된다. 국내 자동차의 폐기물 재활용 기 준인 $85 \%$ 를 만족하기 위해서는 플라스틱, 고무 및 유 리 재질 등에 추가적인 재활용 기술개발이 필요하며, 자 동차 생산업체에서는 안정적인 폐기물 회수 및 관리를 위해 폐기물 회수/재활용 네트워크를 구축하고 있다. 보 통 폐 자동차는 해체를 통해 유용부품을 회수한 후, 압 축하여 press body로 만들고 슈레더 공정을 통하여 철, 비철금속 등의 유가금속을 회수하고 있으며, ASR (Automobile Shredder Residue)이라 불리는 수지류와 유리 및 고무 등의 잔재물은 대부분 소각 및 매립되고 있다.

\subsection{3. 재활용 기술 및 산업 현황}

자동차 접합유리의 경우는 분쇄기로 작은 입자로 분 쇄한 후 흡착분리법으로 PVB 수지와 정제된 유리로 분류하여 포집해야 한다. 강화유리는 강도가 높아 분쇄 공정 시 많은 에너지가 소모되고 분쇄 장치의 마모가 심하게 되며 유리 표면이 코팅되어 있는 경우가 많이 있어 이를 제거하는 추가 공정이 요구되고 있다. 재활 용 공정으로 정제된 유리는 도로포장용, 콘크리트용, 아 스팔트용, 보도블럭용 등의 골재 대용으로 사용되거나 재생유리, 발포유리, 다공성세라믹, 유리질타일, 인조대 리석 등의 상대적인 고부가가치 재료로 사용된다.

자동차의 앞 유리와 뒤 유리는 내부 공간의 밀폐를 위해 유리를 차체에 접착하여 부착하기 때문에 차체로 부터 유리를 분리하기가 어려우며 이를 위해 국내외 자 동차 제조업계에서는 해체분리가 용이하도록 제품의 설 
계부터 폐차 단계까지를 고려하여 친환경제품설계 연구 를 진행하고 있다. 현재 자동차 폐유리는 효과적으로 재 활용할 수 있는 상용기술의 부재 및 낮은 경제성으로 인해 ASR 형태로 파쇄되어 소각 및 매립하고 있으며, 일부 자동차 제조업체를 중심으로 재활용에 대한 연구 개발이 이루어지고 있다.

국내의 경우, 폐자동차의 재활용은 재활용업체에서 폐 자동차를 수거 및 유해물질을 폐기한 후 이를 한국환경 공단에 보고하는 형식으로 진행되며, 폐자동차의 재활 용률을 2009년 85\%, 2015년 95\%까지 올리는 것을 목표로 하고 있다. 환경부와 현대-기아자동차(주)는 폐 자동차 자원순환체계 선진화 시범사업을 2012년 1월 추 진하여 폐차 78,000 대에 대해 고철, 플라스틱 등을 $95 \%$ 까지 재활용하는 시범사업을 착수하였다. 자동차 폐 유리는 일부 업체로부터 파쇄선별 등의 공정을 거쳐 유 리분말 형태로 제조하고 있으며, 국내에서는 서울유리 산업, 경남물산, 서진유리산업 등에서 자동차 폐유리를 재활용 하고 있다. ${ }^{10)}$ 현재 재활용된 자동차 폐유리는 고부가가치 창출이 어렵고, 오히려 처리 비용이 더 높 기 때문에 폐유리 반입 업체로부터 폐기물 처리 비용을 받아 재활용을 하고 있는 실정이다.

\section{3. 디스플레이용 유리}

\subsection{1. 제조 및 생산현황}

영상미디어 시대의 매체 역할을 하는 디스플레이 패 널은 다양한 제조 공법과 고 난이도의 품질관리가 필요 하므로 기술 진입장벽이 높아 몇 개의 공급자들에 의해 독점체계가 유지되는 고부가가치 제품으로 성장하고 있 다. 패널의 종류별 예상 판매량이 Fig. 5에 나와 있다.

현재 $\mathrm{LCD}$ 패널용 유리기판의 세계시장은 한국의 삼성 코닝정밀유리 (30.8\%), 일본의 Asahi Glass (24.4\%), NEG (14.1\%), AvanStrate (6.5\%), 미국의 Corning (24.2\%)에 과 점되어 있으며 일본 업체의 점유율이 점차 확대되고 있 다. 삼성코닝정밀유리는 국내시장 수요량의 약 $65 \%$ 를

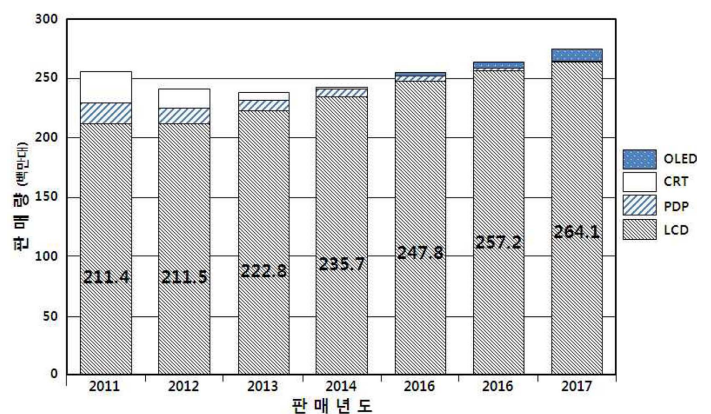

Fig. 5. Sales forecasts of display panels. ${ }^{11)}$

공급하고 있으며, 삼성전자 수요량의 약 $86 \%$ 를 공급하고 있다. 한편 LG 디스플레이는 유리기판 수요의 약 $47 \%$ 를 삼성코닝정밀유리에서 공급받고 있으며, $\mathrm{NEG}$ 에서 약 $41 \%$, 아사히 글라스에서 약 $12 \%$ 를 공급받고 있다. ${ }^{11)}$

\subsection{2. 폐유리 발생현황}

현재 국내에서 발생되는 CRT(Cathode Ray Tube)와 평판 디스플레이(FPD: Flat Panel Display, LCD, PDP, OLED) 전자제품 폐기량 관련된 체계적인 현황 통계 파 악 및 관리 유지는 이루어지지 않고 있으나 예상 수명 을 대략 10년으로 잡으면 Table 4와 같이 2015년부터 약 $200 \sim 300$ 만대 정도의 폐 평판디스플레이 제품이 발 생할 것으로 예측된다.

\subsection{3. 재활용 기술 및 산업 현황}

90년대 대량으로 특허출원이 이루어진 CRT 유리 재 활용 기술은 디스플레이의 해체와 단순 물질 재활용을 위한 전처리 및 건식 처리기술에 관한 것으로 $\mathrm{CRT}$ 의 패널용 유리와 funnel용 유리의 조성이 다르기 때문에 이의 분리 기술을 재활용 요소 기술로 개발하였으며 추 가 공정으로는 이를 위한 전처리 기술과 분리된 부품의 세정기술을 개발하였다. 한편 폐 LCD 재활용 관련 특 허 동향을 분석해 보면 주로 일본의 기업을 중심으로

Table 4. Waste display devices production rate (thousand)

\begin{tabular}{|c|c|c|c|c|}
\hline 구분 & 현재* & ' $15^{* *}$ & '20** $25^{* * *}$ \\
\hline CRT & 5,650 & 2,640 & 1,210 & 554 \\
\hline PDP & 1 & 150 & 2,620 & 220 \\
\hline LCD & 340 & 2,830 & 4 & 3110 \\
\hline LED**** & 0 & 0 & 4,010 & 3,204 \\
\hline 계 & 5,991 & 5,620 & & \\
\hline
\end{tabular}

J. of Korean Inst. Resources Recycling Vol. 22, No. 4, 2013 
출원이 되고 있으며 $\mathrm{LCD}$ 유리를 공정 첨가물 또는 대 체물로 재활용하는 기술, $\mathrm{LCD}$ 로 부터 유리, 액정, 분광 판, 인듬, 광학필름을 분리 및 회수하는 기술, 유리 및 유가금속의 재활용/무해화 처리 공정 등이 주를 이루고 있는데 전반적으로 LCD 패널 유리에 관한 국내외 특 허가 가장 많이 출원되었다. ${ }^{22}$

(1) CRT 유리의 재활용 기술 및 산업 현황

CRT 제품의 중량대비 재질 구성은 금속 $16.4 \%$, 유 리 $61.7 \%, \mathrm{PCB}$ 및 기타 소재 $6.7 \%$, 플라스틱 $14.4 \%$ 정도로 이루어져 있고 유리, $\mathrm{PCB}$ 및 기타소재의 재활 용 단가는 대략 12.5 원 $/ \mathrm{kg}$ 으로 평가됨에 비추어 볼 때 재료 재활용 시의 경제성 분석 결과 231 원 $/ \mathrm{kg} \mathrm{CRT}$ TV이다. ${ }^{11)}$ 현재 $\mathrm{CRT}$ 의 국내 제조가 중단되었고 CRT cullet 재활용 공장이 완전 폐쇄되어 국내의 폐 CRT 유리 보관처에 거의 포화 상태에 이르러 있는 CRT 유 리를 타원자재로 사용할 수 있는 재료 재활용 방안을 시 급하게 확보할 수 있다면 국내의 전기전자 제품 및 자동 차의 자원순환에 관한 법률 제8405호 (2007.4.27.)에 의 거 환경 부하도 경감시키고 수익성도 확보할 수 있다.

최근 일본의 파나소닉에서는 Fig. 6과 같이 폐 CRT 에서 해체한 유리를 이용하여 유리 섬유를 제조하고 이 를 냉장고 등의 제조에 진공 단열재로 사용하는 양산 공정을 가동하고 있는 점에 비추어 향후 유사한 응용 분야를 넓혀 나가고 특허 쟁점을 회피할 수 있다면 국 내에서도 이러한 재활용 기술을 벤치마킹 할 수 있을 것으로 판단된다. ${ }^{13)}$

(2) LCD, PDP 유리의 재활용 기술 및 산업 현황 (1)에서 기술된 $\mathrm{CRT}$ 구성 소재의 단가를 $\mathrm{LCD}$ 와
$\mathrm{PDP}$ 에 적용 해 본다면 2007년도 단가 기준으로 $\mathrm{kg}$ 당 PDP TV 434원, LCD TV 467원이다. ${ }^{11)}$ 주목할 것은 최근 일본 Sharp에서 액정 패널 유리의 재자원화 공정 을 개발하였는데 Fig. 7을 보면 먼저 폐 액정 유리를 파쇄하여 큰 덩어리는 물이 통과할 수 있는 보도블록, 건축자재, 표찰을 만들고 미세한 분말은 고기능성 도료 를 제조하는데 사용한다. ${ }^{13)}$ 한편 국내 고등기술연구원에 서는 폐평판디스플레이 제품의 토탈 리사이클링 기술을 개발 중에 있다. 이는 금속 이외에 유리, 플라스틱 등 모든 재질의 폐 부품을 재활용하는 것으로 상용화 기술 개발을 목표로 하고 있다. ${ }^{14)}$

\section{4. 석영유리}

2.4.1. 제조 및 생산현황

석영유리는 $\mathrm{SiO}_{2}$ 만으로 이루어진 고순도의 특수유리 로, 기타 금속 불순물의 함량이 매우 적은 유리이기 때

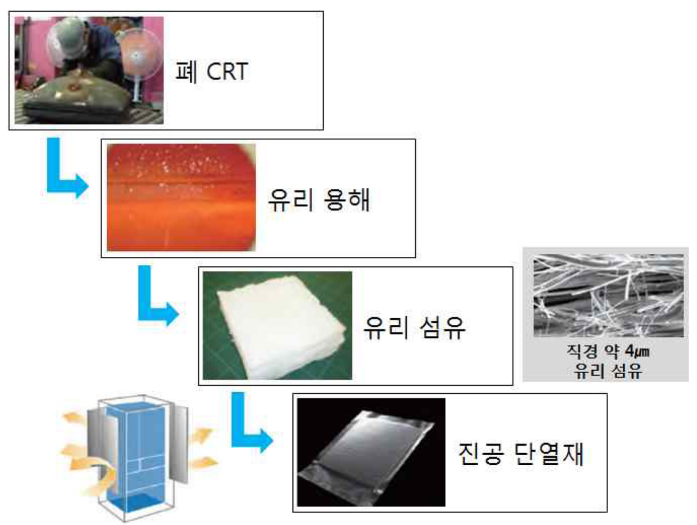

Fig. 6. Panasonic's CRT glass recycling technology.

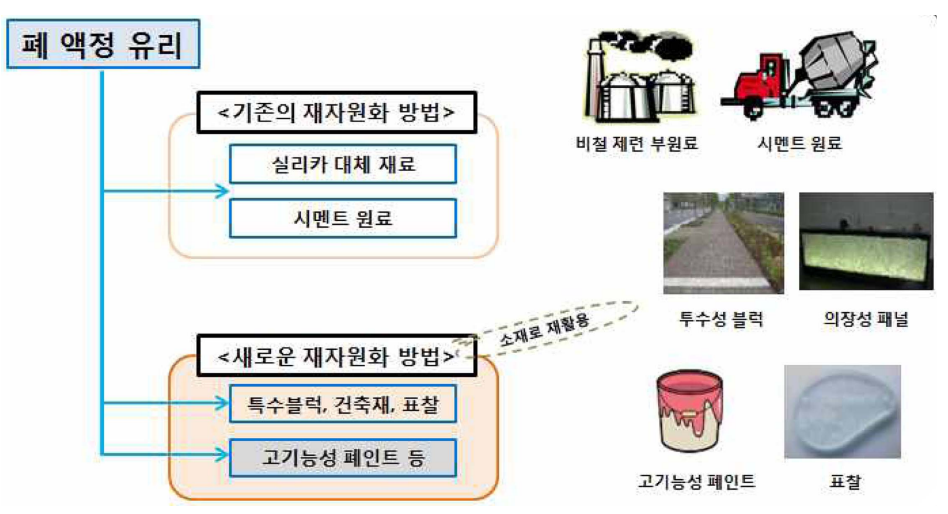

Fig 7. Sharp's LCD glass recycling. 
Table 5. Quartz glass classification by production method ${ }^{1)}$

\begin{tabular}{|c|c|c|c|c|}
\hline 분 류 & 1종 & 2종 & 3종 & 4종 \\
\hline 원료 & 수정 & 수정 & $\mathrm{SiCl}_{4}$ 외 규소화합물 & $\mathrm{SiCl}_{4}$ 외 규소화합물 \\
\hline 제조방법 & $\begin{array}{c}\text { 아크, 플라즈마, } \\
\text { 전기로분위기(진공,불활성) }\end{array}$ & $\begin{array}{l}\text { 화염(산,수소) } \\
\text { (탄화수소,산소) }\end{array}$ & $\begin{array}{l}\text { 화염(산,수소) } \\
\text { (탄화수소,산소) }\end{array}$ & $\begin{array}{c}\text { 고주파 유도플라즈마 } \\
\text { (산소,산소+Ar) }\end{array}$ \\
\hline $\begin{array}{c}\text { 화학적특징 } \\
(\mathrm{OH} \text { 함량) } \\
\text { (금속불순물) }\end{array}$ & $\begin{array}{c}10 \mathrm{ppm} \\
50 \sim 100 \mathrm{ppm}\end{array}$ & $\begin{array}{l}100 \sim 300 \mathrm{ppm} \\
\quad<100 \mathrm{ppm}\end{array}$ & $\begin{aligned} 800 & \sim 1300 \mathrm{ppm} \\
& <1 \mathrm{ppm}\end{aligned}$ & $\begin{array}{l}<5 \mathrm{ppm} \\
<1 \mathrm{ppm}\end{array}$ \\
\hline 응용범위 & $\begin{array}{c}\text { 램프재료(할로겐,크세논,수 } \\
\text { 은등의 램프튜브) } \\
\text { 반도체용(로심관,치구 등) } \\
\text { 공학용(적외선용) } \\
\text { IC봉지재 }\end{array}$ & $\begin{array}{c}\text { 반도체용 } \\
\text { (로심관,치구,세정조 등) } \\
\text { 광학용(렌즈,프리즘 등) } \\
\text { IC봉지재 } \\
\text { 광섬유관 } \\
\text { 실리카유리섬유 }\end{array}$ & $\begin{array}{c}\text { 광학용(렌즈,프리즘,셀 등) } \\
\text { 광섬유관 } \\
\text { 실리카유리섬유 } \\
\mathrm{IC} \text { 봉지재 } \\
\text { 포토마스크 }\end{array}$ & $\begin{array}{c}\text { 광학용(적외,자외) } \\
\text { 섬유봉(봉,관) }\end{array}$ \\
\hline
\end{tabular}

문에 화학적 안정성이 매우 우수하며, 자외선 영역에서 의 투과율이 뛰어나고, 내열성(연화점: $\left.1700^{\circ} \mathrm{C}\right)$ 이 우수 한 재료이다. 석영유리는 초기에 독일의 Heraeus사에서 자연에서 산출되는 석영결정을 용융하여 만들었으나, 이 후에 합성석영유리(synthetic quartz glass) 등 화학적인 합성법으로 석영유리를 제조하는 방법이 개발되었다.

석영유리 소재의 세계시장 규모는 2007년 기준으로 반도체 및 디스플레이 포토마스크용이 약 1 조 원, 반도 체 및 디스플레이 공정용 부재류가 1.5 조 원, 광파이버 및 광학용 약 1 조 원, 석영도가니 1.5 조 원 및 기타 약 0.5 조 원 등 약 5.5 조 원 정도로 조사되고 있으며, 품목별로 연평균 $5 \sim 20 \%$ 의 성장률을 보이고 있으므로 2010년 기준 약 6조 원 이상의 규모로 추정된다1). 국 내 석영유리 시장은 아직 국산화가 이루어지지 않아 전 량 수입에 의존하고 있으며, 최근 반도체, 디스플레이 및 광학산업의 급격한 성장으로 인해 2009년 약 6천억 원, 2010년 기준으로 8천억 원 정도의 시장 규모로 크 게 확대되었다. ${ }^{1)}$

\subsection{2. 폐유리 발생현황}

석영유리는 산업원자재인 디스플레이, 반도체, 광통 신, 광학, 조명 산업 부품으로 폭넓게 사용되고 있기 때문에 실제 폐유리 발생량 통계수치로부터 폐석영유리 의 발생 규모는 아직까지 공식적인 통계자료가 없다. 따 라서 석영유리제품 국내 수출입 현황을 바탕으로 석영 유리제품의 life cycle을 3년으로 가정하였을 때, 2012 년에는 약 2,556 톤 규모의 폐석영유리가 발생할 것으로 예측된다.

폐석영유리는 제조 또는 가공업체의 품질검사 공정을
거쳐 발생되는 유리불량품인 internal cullet이 대부분으 로, 석영유리모재를 수입하여 가공하는 국내 업체의 경 우에는 가공 후 발생된 자투리 유리는 재사용 하고 있 다. 또한 반도체 및 디스플레이 제품 제조사에서는 석 영유리의 높은 단가로 인해 In-house 개념으로 직접 석 영유리의 제조 및 부품화가 진행 중이다. ${ }^{15)}$

\subsection{3. 재활용 기술 및 산업 현황}

수집된 폐석영유리는 재활용 플랜트에서 visual 검사 후, 사용가능한 폐석영유리에 대해 파쇄단계를 거쳐 크 기별 분류 또는 세척을 실시하고, 이후 선별과정을 거 쳐 표면 유기물을 제거하여 cullet 형태로 처리 후 제 조사로 넘겨지고 있다. 초기 특수한 목적으로 제조된 석 영유리는 다시 본래의 용도에 맞는 석영유리로 재생 또 는 재제조가 가능하며, flux 형태로 다른 유리상품을 제 조할 때 사용되기도 한다. 그리고 Re-melting 공정을 거 치지 않은 일부 석영유리는 다른 폐유리와 마찬가지로 투 수성이 우수한 블록이나 조리대 등에 응용되고 있다.

국내에서의 석영유리 재활용은 대부분 석영유리기판 을 세정하거나 열성형하여 다시 기판재로 재활용하거 나, 석영입자와 분말로 가공하여 코팅재로 재활용하기 도 한다. 국내의 주요 재활용 기술을 살펴보면, 폐석영 유리를 입자와 분말로 가공하여 각종 렌즈나 타겟의 진 공 증착용 코팅재료로 재활용하고 있으며, ${ }^{16)}$ 세정을 통 하여 반도체 Diffusion 공정에서 사용된 Quartz를 재활 용하고 있다. ${ }^{17)}$ 또한 석영돔 (dome) 진공 열성형 기술 을 이용해 파기된 석영글래스를 다양한 규격의 판재 글 래스로 리사이클링하는 기술을 개발하여 폐석영유리를 재활용하고 있다(Fig. 8). ${ }^{18)}$ 


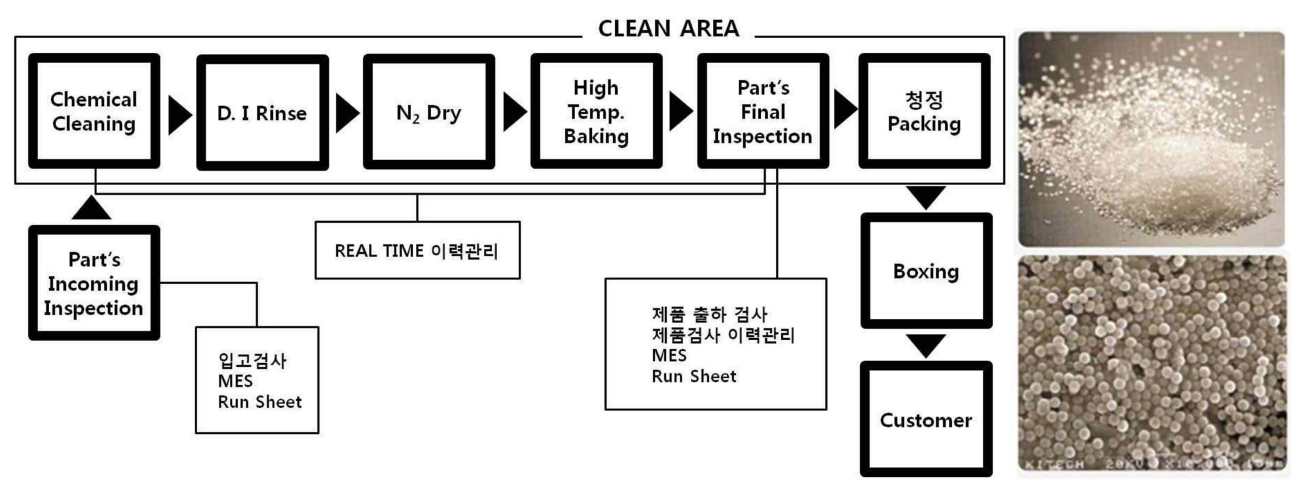

Fig. 8. Waste quartz glass washing process ${ }^{17)}$ and ground powder. ${ }^{16)}$

\section{5. 태양전지용 유리}

\subsection{1. 제조 및 생산현황}

태양전지용 유리는 결정질 실리콘 태양전지 및 박막 형 태양전지(a-Si, CIGS, CdS/CdTe)에 있어서 모듈을 보호하는 커버유리로 사용되며, 염료감응형 태양전지의 경우는 투명전도막이 코팅된 전후면 기판유리로 이용된 다. 이러한 태양전지용 유리의 가장 큰 특징은 모듈의 효율향상을 위해 광투과도가 매우 우수한 저철분 $(150 \sim 200 \mathrm{ppm})$ 백색유리를 사용한다는 것이다. 또한 열강화공정을 통해 충격강도가 일반유리에 비해 3 배 이 상 높고 내열성도 향상되어 파괴 시 아주 작은 조각으 로 깨지는 특징이 있다. 태양전지 산업용 유리의 세계 적인 규모는 2009년도에 약 $11.7 \mathrm{GW}$ 수준으로 이를 유리 면적으로 환산하면 약 $114,523 \mathrm{ksqm}$ 정도이고 무 게로 환산 시 약 $900 \mathrm{kton}$ 인 것으로 분석된다. 연도별 태양전지용 유리의 수요는 Fig. 9 와 같이 지속적으로 늘어날 것으로 예상되나 2011년도부터 태양전지의 수요 위축과 중국업체를 주축으로 한 꾸준한 증설을 통해 유 리 산업의 수요 공급은 이미 밸런스를 확보하고 있는 것으로 나타났다.

\subsection{2. 폐유리 발생현황}

태양전지 모듈의 생산은 1998년에 최초로 이루어졌 으므로 본격적인 폐모듈의 발생은 2020년 이후라고 할 수 있다. ${ }^{19)}$ 따라서 모듈 생산 시 발생하는 불량품을 제 외하면 아직까지는 태양전지용 폐유리가 거의 발생하지 않으며 그 수량을 파악하는 것은 쉽지가 않다. 대만의 경우 1 년에 약 1,000 톤의 폐모듈이 발생한다는 보고가 있으나 신빙성있는 조사라고 보기엔 무리가 있다고 여 겨진다. ${ }^{20)}$

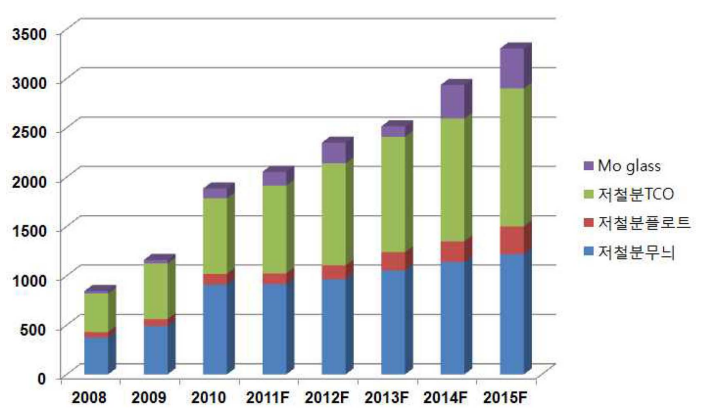

Fig. 9. World sales forecast of solar cell glass.

\subsection{3. 재활용 기술 및 산업 현황}

태양전지용 유리의 재활용은 일반적인 유리(유리병, 창문 등)의 재활용 공정과 유사하게 파쇄 공정을 거치 게 된다. First Solar사의 경우 수명이 다 된 모듈을 건식으로 파쇄한 후 습식법을 통해 반도체 물질과 유리 부스러기로 재활용하고 있다(Fig. 10).

재활용 산업에 있어서 가장 중요한 것으로써, 태양전 지용 유리의 재활용에 대한 경제적 이득을 계산해 보아 야 한다. 보고된 자료에 따르면 $1 \mathrm{~m}^{2}$ 의 크기를 갖는 태 양전지 모듈을 재활용했을 때 Table 6에 나타낸 경제적 이익을 얻을 수 있다. ${ }^{19}$

Table 6에 따르면 CIGS를 제외한 다른 태양전지 모 듈을 재활용할 경우 경제적인 손실을 보는 것으로 나타 났다. 이러한 경제적 불이익 때문에 산업계에서는 태양 전지 모듈 재활용을 꺼려할 것으로 예상할 수 있다. 앞 서 언급한 바와 같이 2020년 이후에는 많은 태양전지 폐모듈이 발생할 것이고, 그것들을 효과적으로 재활용 하기 위해서는 기술력의 향상 및 공정비용 절감에 대한 연구가 선행되어야 할 것이다. 또한, 태양전지용 유리는 


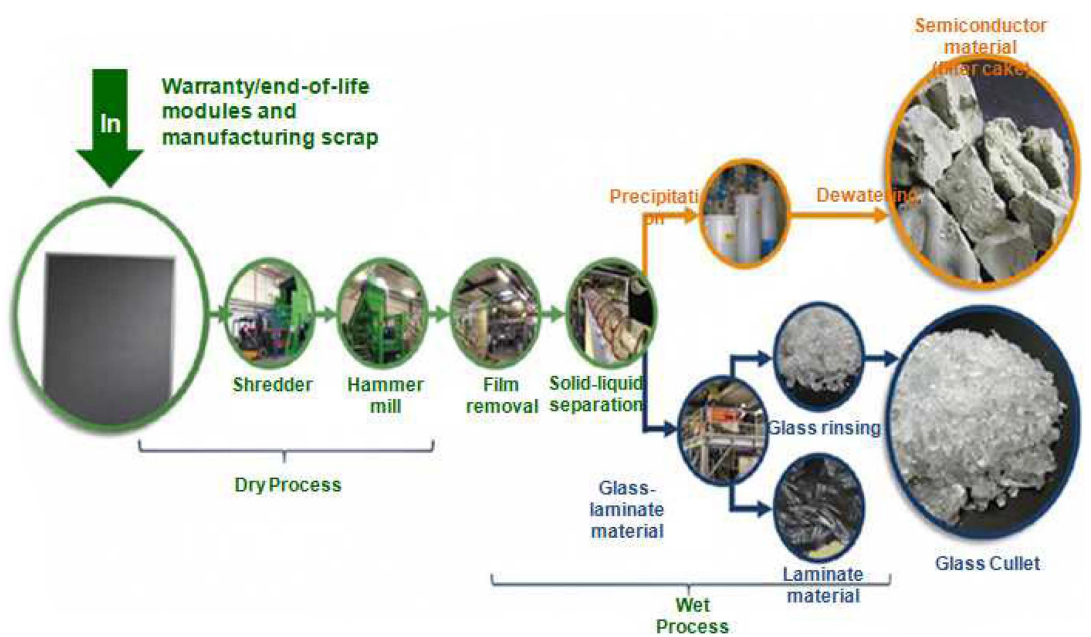

Fig. 10. First Solar's module recycling technology.

Table 6. Profits of Solar cell module recycling ${ }^{19}$

\begin{tabular}{|c|c|c|c|c|}
\hline & CIGS & CdTe & c-Si & p-Si \\
\hline 재활용 이익 (USD) & 22.25 & -0.24 & -23.96 & -23.99 \\
\hline
\end{tabular}

*CIGS: copper indium gallium diselenide, CdTe: cadmium telluride, p-Si: poly-crystalline silicon, c-Si: mono-crystalline silicon.

저철분 강화유리로써 투명도와 안전성 면에서 우수하므 로 재활용 시 파쇄하기 이전에 새로운 용도로의 재사용 이 가능하도록 선별 및 해체/분리 기술을 개발하는 것 이 비용절감과 재활용 효율을 극대화하는 방법이라고 사료된다.

\section{6. 화학강화유리}

\subsection{1. 제조 및 생산현황}

화학강화유리는 유리를 화학 처리하여 강도를 부여하 는 일종의 가공 유리이기 때문에 특정한 조성만이 화학 강화가 되는 것은 아니며, 대부분의 유리는 화학강화가 가능하다. 하지만 화학강화 처리 후의 효과가 매우 높은 일부 유리를 화학강화 유리로 특별히 표현하고 있다. 화 학강화유리는 휴대폰, 공업용 터치스크린, 게임기, 태블 릿 $\mathrm{PC}$, 노트북, 카메라 등 개인 IT 제품에서 $\mathrm{DID}$ (Digital Information Display)와 태양전지 보호 유리 등과 같은 공공재에 적용할 수 있으며, 2011년 기준으 로 스마트폰의 판매량이 급신장하고 있는 추세로 화학 강화유리의 시장규모는 스마트폰의 경우 약 9.4억 달 러 규모로 추정되고 있으며, 휴대폰 이외의 시장규모 를 고려하면 약 11 억 달러가 넘는 것으로 판단된다 (Fig. 11).

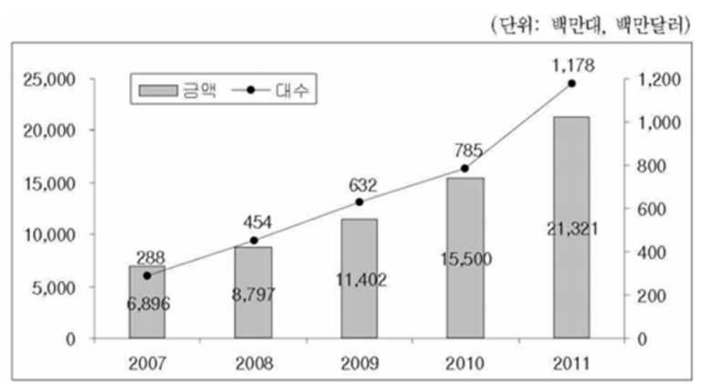

Fig. 11. Touch screen panel production rates (expectation).

\subsection{2. 폐유리 발생현황}

대부분의 화학강화유리는 스마트폰이나 Tablet $\mathrm{PC}$ 에 적용되고 있는 실정으로, Fig. 12에 나타낸 것처럼 2009년을 기점으로 스마트폰의 보급이 본격화 되고 있 으며, 2010년 기준으로 스마트폰은 약 700 만대 가량 판매된데 이어, 2011년 3분기까지 누적 판매량은 약 1400 만대로 나타났다. ${ }^{8}$ 스마트 모바일 시대의 합리적 단말 이용 구조 정착을 위한 정책방안 연구에 의하면, 국내 휴대폰의 교환주기는 2010년 기준 26.9개월, 2011년 기준 약 27개월 정도로 보고되고 있어 스마트 폰을 기준으로 교체된 스마트폰이 모두 수거된다고 가 


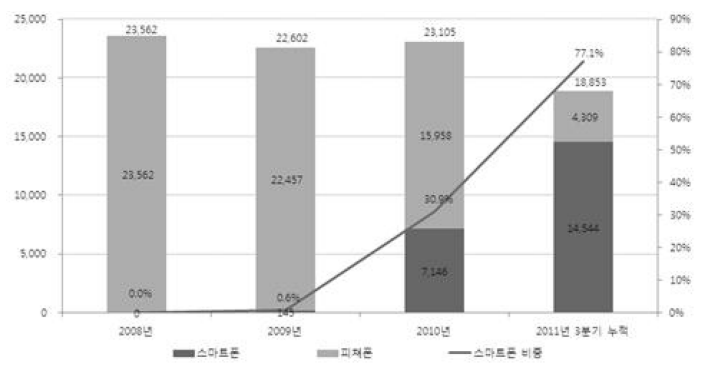

Fig. 12. Mobile phone production rate and smart phone ratio change (unit: thousand).

정했을 경우 폐기되는 화학강화유리가 2014년 이후 년 간 1400 만장 이상이 될 것으로 추정할 수 있다. 또한, 2011년 9월 기준 약 50만 명이 Tablet PC를 이용하고 있는 것으로 추정되고 있으며, 국내 Tablet PC 이용자 수는 2010년 말 18만 명에서 2012년 383만 명, 2015 년에 982만 명에 달할 것으로 전망된다. ${ }^{21)}$ 따라서, Tablet PC의 교체주기를 4년으로 가정했을 때, 2016년 이후에는 폐기되는 화학강화유리가 기하급수적으로 증 가할 것으로 예상된다.

\subsection{3. 재활용 기술 및 산업 현황}

화학강화유리는 현재 스마트폰이나 Tablet $\mathrm{PC}$ 의 cover glass로 이용되고 있지만 점점 그 용도가 증가하 여 수족관용 유리, 건축용 유리 및 태양광 모듈 보호 유리로 사용처가 확대되고 있는 실정이며, 일반 강화유 리에 비해 강도가 높고, 가공이 쉽다는 장점을 가지고 있어 ${ }^{22)}$ 대형 화학강화유리를 절단하여 소형 크기의 제 품에 사용될 가능성이 높다. ${ }^{23)}$ 그러므로 Tablet $\mathrm{PC}$ 의 Cover glass를 회수하여 절단 후 스마트폰 용 Cover glass로 사용할 수 있으나, 절단면이 강화 처리되어 있 지 않은 단점이 있어 이에 대한 처리기술의 개발이 필 요한 실정이다.

일반적인 유리의 재활용의 문제점은 사용 후 폐기되 는 유리에 따라 조성이 다르다는 문제점이 있다는 것이 다. 따라서 고품질의 유리를 재활용하기 위해서는 조성 이 같은 유리별로 재생 공정이 이루어져야 효율성이 높 다고 할 수 있다. 특히, 화학강화유리에 사용되는 모재의 경우 제조사가 미국의 Corning(알루미노 실리케이트 글 라스)과 일본의 Asahi glass(소다석회유리)로 다른 유리에 비해 일정한 성분을 가지고 있어 모재의 성분에 따라 분 류 후 유리에 함유되어 있는 성분의 추가 또는 제거를 통해 고부가가치의 유리 생산이 가능하리라 사료된다.
앞에서 언급한 Reuse나 Recycle 공정은 일반적인 유 리 생산 공정과 비교했을 때 경제적인 측면에서 유리하 다 볼 수 없다는 관점이 ${ }^{24-25)}$ 지배적으로, 그 대안으로 폐유리에 포함되어 있는 알카리성분이나, 금속성분을 상 분리 방법을 통해 분리하여 고순도의 실리카를 제조하 는 방법이 제시되고 있으며, 상분리 방법으로 제조된 실 리카의 경우 순도가 약 $99.5 \%$ 이상인 것으로 알려져 있다. ${ }^{25)}$

\section{3. 맺음말}

최근 유리제품 폐기물의 발생량이 증가하고 있는 추 세로 이로 인한 환경오염 및 순환가능 자원의 낭비문제 가 심화되고 있다. 정부에서도 2003년부터 생산자 책임 재활용제도를 운영하고 있으며 다양한 폐기물의 재활용 을 추진하고 있다. 지금까지 금속자원 순환에 대한 관 심과 기술개발투자에 비해 폐 유리제품의 재활용은 주 목받지 못하였다. 하지만 WEEE에서도 폐제품의 재활 용률을 무게비로 정하고 있어 유리의 재활용은 앞으로 필수적일 것으로 판단된다. 따라서 폐유리 재활용 분야 에 대한 기술개발이 시급하며 정부에서 여러 정책적 지 원이 필요하고 더불어 산학연관의 연계기술개발이 필요 할 것으로 생각된다.

폐유리 재활용의 특징은 다량의 폐유리가 발생한 다 는 것인데, 재활용기술의 상용화를 위해서는 첫째, 폐유 리 제품의 고부가가치화가 필요하며 둘째, 폐유리를 대 량으로 수용할 수 있는 수요처를 확보하는 것이 필수적 으로 이를 이룬다면 폐유리 재활용의 미래는 희망적이 라고 할 수 있다. 특히, 유리는 반도체, 디스플레이 등 우리나라가 국제적으로 글로벌 경쟁력을 갖고 있는 제 품들의 핵심소재로 사용되면서 원소재는 아직 수입에 의존하지만, 가공 및 제품제조기술에 대한 오랜 기간의 축적된 노하우를 갖고 있으므로 재활용 기술 역시 국제 적인 선도기술을 창출해 낼 수 있을 것으로 판단되어 진다.

폐유리 발생현황분석 같은 재활용 관련 통계 파악은 재활용 기술개발의 선결 조건이라고 할 수 있다. 하지 만 본 고에서도 밝힌 바와 같이 폐 스마트 유리의 경 우 국내에서의 배출현황, 스크랩 유통현황, 폐기현황, 관 련기업 실태 등에 대한 분석이 매우 열악한 실정이다. 따라서 이에 대한 적절한 투자가 이루어진다면 빠른 기 간 내에 최고의 기술을 보유하고 재활용 선진국으로 경 쟁력 확보가 가능할 것이다. 


\section{참고문헌}

1. Korea Institute of ceramic Engineering and Technology, 2010: Investigation on Industrial Competitiveness of Smart Glass, Report of Korea Trade Commission.

2. Korean Institute of Resources Recycling, 2009: Recycling White Book, Chung Moon Gak..

3. Institute for Advanced Engineering, 2013: IAE Annual Report TM2013-01

4. Korea Lighting Recycling Coporation : http://www.rlamp. co.kr/subpage.php? $\mathrm{p}=\mathrm{m} 24$.

5. The Dow Chemical Company : http://www.amberlyst.com/ mercury.htm.

6. Seung-Whee Rhee et al., 2012: A Numerical Simulation on Separation of Phosphor from Spent Fluorescent Lamp, J. Kor. Soc. of Waste Management, 29(3), pp. 281-287.

7. Statistics Korea: http://kosis.go.kr

8. Hyun Tae Joung et al., 2006: Properties of Automotive Waste Glass and a Study of Manufacturing Technique of Artificial Marble, Journal of Korea solid wastes engineering society, 23(5), pp.359-365.

9. Korea Automotive Technology Institute, 2009: Trends for Automotive Recycling.

10. Ministry of Environment, 2009: A Study on effective recycling of dissembled modules from waste automotive, 111480000-001072-01.

11. Korea Display Bank Data (Display Market Trend for $4 / 4$ of 2005): www. displaybank.com/_kor/research/markettrack_ view.html?id=1517.

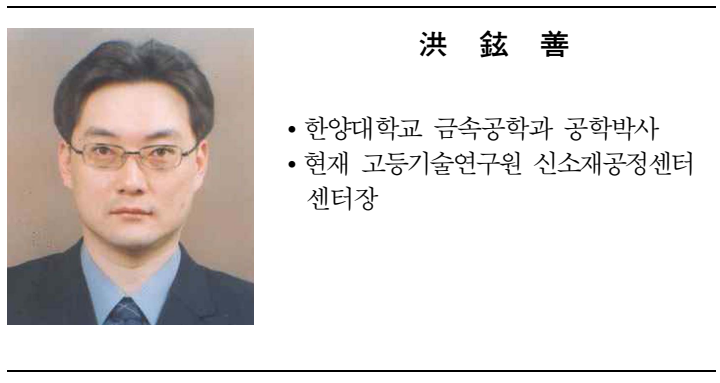

12. Sungkyu Lee et al., 2012: Trend on Recycling Technologies for Display Wastes analysed by the Patents and Literature Review, Journal of the Korean Institute of Resources Recycling, 21, pp.65-73.

13. Panasonic Corporation Sustainability Report 2012, pp.11.

14. Hyun Seon Hong et al,, 2010: Overview and Future Concerns for Recycling Display Wastes, Korea Industrial Chemistry News, 13(1), pp. 10-19.

15. Vieitez E.R. et al, 2011: End-of-Waste Criteria for Glass Cullet:Technical Proposals, JRC-IPTS.

16. Youth Tech Korea : http://youthtechkorea.kr.ec21.com/ company_info.html.

17. Wonik QnC Coporation : http://www.wonikquartz.com.

18. Chemlocus : Q-Tech Recycling of Quartz, Chemical Journal 2003/7/22.

19. McDonald N.C. et al, 2010: Energy Policy, 38, pp.70417047.

20. Lin, K-L. et al, 2012: Environmental Progress \& Sustainable Energy, 31, pp.612-618.

21. Korea Information Society Development Istitute, 2011 : A sutudy on Policy for Building the Rational Using Structure of Mobile Phones in a Smart Mobile Era 11-진흥-가-19.

22. CARA : http://www.caraco.co.kr/kr/product_application.html.

23. 社法人電子情報技術產業協JEITA) ディスプレイデバイス 部：FＰＤ(フラットパネルディスプレイ)のガラスリサイ クル技術課題と 取組み一資源循環型社に向けて。

24. Tooru Kudo, 2008: Recycling Flat Glass, Reports Res. Asahi Glass Co., Ltd., 58, pp.7-15.

25. Tomoko AKAI, 2006: New methods of recycling waste glass, NEW GLASS, 21(1), pp.15-21.

\section{曺 奉 圭}

- 현재 한국지질자원연구원 책임연구원

• 당 학회지 제 18 권 5 호 참조 